\title{
A threatened new species of Dioscorea from KwaZulu-Natal, South Africa, Dioscorea hurteri (Dioscoreaceae)
}

\author{
Ryan Hills ${ }^{1}$, A. Muthama Muasya ${ }^{2}$, Olivier Maurin ${ }^{3} \&$ Paul Wilkin $^{3}$
}

Summary. Morphological character data are used to show that a distinct morphotype of Dioscorea L. from KwaZuluNatal in South Africa is an undescribed species, related to the D. buchananii Benth. species complex but differing in its inflorescence and floral morphology from all other taxa. It is described as Dioscorea hurteri R. Hills \& Wilkin, illustrated and a distribution map and ecological information provided. It is known from four localities, just two of which may be protected, within a heavily developed region of South Africa and with an extent of occurrence (EOO) of $9,872 \mathrm{~km}^{2}$. Thus, its provisional IUCN conservation status is vulnerable (VU).

Key Words. Conservation, distribution, morphology, vulnerable, yam.

\section{Introduction}

The taxonomic history of the Dioscorea buchananii Benth. species complex was summarised in Wilkin \& Muasya (2015). Among the 15 species of Dioscorea found in South Africa, the taxa of the complex share perennial, subterranean tubers, left-twining habit, a tendency to possess palmately lobed leaves (but with entire leaves in some to many populations), relatively short spicate to racemose inflorescences, paired floral bracts and flowers with well-developed receptacles and seeds that are winged all around the margin but with a wing that is longer than wide (often oblong-elliptic). The highest diversity is found in KwaZulu Natal. The complex was demonstrated by Maurin et al. (2016) to be sister to the rest of the Africa clade taxa. The distribution of the clade extends from the eastern part of the Eastern Cape through KwaZulu-Natal and eastern South Africa to southern tropical Africa. The former area holds three taxa, D. rupicola Kunth, D. multiloba Kunth and D. buchananii subsp. undatiloba (Baker) Wilkin, while a single species (D. buchananii subsp. buchananii) is found from Tanzania and Southern and Eastern Congo (Kinshasa) to southern Mozambique, Zimbabwe and Angola. Wilkin \& Muasya (2015) recommended further research on the Limpopo and KwaZulu-Natal populations of D. buchananii subsp. undatiloba given their rarity, lack of recent collections and leaf morphological differences. They also tentatively linked the specimen Pole Evans 4854, collected from Ixopo in KwaZulu-Natal (presumably as a tuber, later flowering in cultivation), to D. multiloba, but noted that the presence of short pedicels and the tepal and torus (receptacle) dimensions suggested potential introgression with D. buchananii subsp. undatiloba. The two taxa are sympatric in KwaZulu-Natal. The species complex would benefit from an extensively sampled population-based study using molecular marker data, especially concerning the taxa in KwaZulu Natal. Since the publication of Wilkin \& Muasya (2015) the authors have been sent photographs of D. buchananii subsp. undatiloba from Mpumalanga taken in 2005, although the site has since been developed for human habitation. However, the photographs both greatly increase its extent of occurrence and provide evidence that it is likely to still occur in northeastern South Africa. The most recent collection among the herbarium specimens of the subspecies was from 1921.

During research to develop conservation assessments for South African Dioscorea species (Hills 2016), the first author examined an image of a specimen belonging to this species group that did not match the description of any of the taxa described above. It exhibited short, very dense male inflorescences with rounded floral buds and tepals that were described as mauve-maroon on the specimen label of Moore s.n. The characters listed above in addition to the depressions in the torus (Fig. 1D) link the specimen to PoleEvans 4854 and a photograph of a male plant taken at Ngome by Johan Hurter in 2002. Additionally, another

\footnotetext{
Accepted for publication 27 February 2018. Published online 26 March 2018

15 Ashentree Cottages, Preston Hill, Wingham, Canterbury, Kent, CT3 1DA, UK.

2 Department of Biological Sciences, University of Cape Town, Private Bag X3, Rondebosch, 7701, South Africa.

3 Royal Botanic Gardens, Kew, Richmond, Surrey, TW9 3AE, UK. e-mail: p.wilkin@kew.org
} 
specimen image (Strey 7038) that had similar inflorescences to these specimens was examined. A female specimen (Pole-Evans 4862) was also identified as exhibiting morphological similarities to these male specimens such as the depressions in the torus. These four specimens were evaluated against the other members of the D. buchananii complex using morphological character data to test the hypothesis that it represented a distinct taxon.

\section{Materials \& Methods}

The primary data used in this study are derived from examination of specimens from the following herbaria: B (images), BOL, BM, K, P, PCE, PRE, NU (images) OXF, TCD and WAG and for Dioscorea buchananii COI, LISC, LMU, MAL and SRGH. Character data for D. buchananii previously published in Wilkin (2001, 2009) were also included. The characters given in the descriptions were scored or measured using the naked eye, a dial caliper or a dissecting microscope with a graduated eyepiece. Leaf lobe length measurements were made along the central vein from the point of insertion of the petiole onto the leaf blade to the central lobe apex. Fig. 1 was prepared using the specimens cited in the legend.

Digital latitude and longitude were obtained for the four specimens of the novel morphotype via georeferencing using online gazetteers and the point-radius method. In addition to the specimenbased locations, three further occurrences were identified as sight records via photographs obtained from Dr Neil Crouch. The specimens of Dioscorea multiloba and D. rupicola cited in Wilkin \& Muasya (2015), Hills (2016) and Hills et al. (in prep.) and the three sight records were used to generate Map 1, which was created using QGIS (Quantum GIS Development Team 2017). These data were also imported into GeoCAT (Bachman et al. 2011; http:// geocat.kew.org/) in order to calculate extent of occurrence (EOO) and area of occupancy (AOO).

\section{Results}

Table 1 shows that the novel morphotype differs discretely from Dioscorea buchananii in male flower pedicel length $(0.2-0.9 \mathrm{~mm}$, as opposed to $1.7-5$ $\mathrm{mm}$ ). Male flower tepal and torus dimensions overlap but those of the new entity are in the lower part of range in D. buchananii. Dioscorea buchananii lacks nectariferous depressions in its flowers, which are pale green or greenyellow to purple-, pink- or bronze-hued, rather than dark purple; they are also less dense on the inflorescence axis. The novel morphotype differs from D. multiloba in male flower pedicel length (sessile to $0.2 \mathrm{~mm}$ long in D. multiloba, against $0.2-0.9 \mathrm{~mm})$, tepal width $(1.3-2.5$ as opposed to $0.7-1.5 \mathrm{~mm}$ ) and torus
Fig. 1. Above ground vegetative and reproductive organ morphology in Dioscorea hurteri. A habit of fruiting plant, showing leaf size variation; B habit of male plant, showing solitary, relatively short inflorescences; $\mathrm{C}$ male inflorescence and a single node, showing the (sub)globose bud shape and flowers concealing the inflorescence axis; $\mathbf{D}$ male flower with two stamens and two tepals removed, viewed at an angle of c. $45^{\circ}$; $\mathrm{E}$ intact male flower viewed from above; $\mathrm{F}$ male flower with androecium removed showing the torus and cordate nectariferous depressions; G female flower in longitudinal section; $\mathrm{H}$ female flower viewed from above, tepals removed, showing the staminodia and gynoecium morphology; J female flower from above, tepals and styles removed, latter excluding bases, the torus and cordate nectariferous depressions. Scale bar: A, B $2 \mathrm{~cm}$; C $1 \mathrm{~cm}$; D $3.3 \mathrm{~mm}$; E - J 4 mm. From PoleEvans 4862 (A, G, H, J), Pole-Evans 4154 (B, D, E, F), photograph (C). DRAWN BY LUCY SMITH.

diam. (2.1 - 3.3 vs 1.5 - $2.3 \mathrm{~mm})$. Male flower nectariferous depressions are only present in D. multiloba and the new entity, but are 0.35 $0.6 \mathrm{~mm}$ in diam. and circular to ovoid in outline in the former (Wilkin \& Muasya 2015) and $0.8-1.2 \times$ $0.4-0.7 \mathrm{~mm}$ and reniform to cordate in outline in the latter (Fig. 1). Female flowering plants of D. multiloba and the new entity also are the only ones to possess nectariferous depressions, with a similar shape difference to male plants. In addition, the novel morphotype has c $1.1 \mathrm{~mm}$ high, almost completely divided, apically recurved styles, while D. multiloba has fused styles that are c. $1.0 \mathrm{~mm}$ long, erect, stout and 3-angled with only the three stigmatic surfaces free and spreading. It differs from $D$. rupicola in numerous characters, including stamen number. Thus, the novel species is described below as a new species, Dioscorea hurteri $\mathrm{R}$. Hills \& Wilkin.

GeoCAT yielded figures of $9,872 \mathrm{~km}^{2}$ for EOO and $20 \mathrm{~km}^{2}$ for AOO based on a user defined cell width of $2 \mathrm{~km}$, as recommended by IUCN Standard and Petitions Subcommittee (2014).

\section{Description}

Dioscorea hurteri $R$. Hills $\mathcal{E}$ Wilkin sp. nov. Type: South Africa. KwaZulu-Natal: Camperdown, Drummond, ő fl. Oct. 1964, Moore s.n. (holotype NH!).

http:/ /www.ipni.org/urn:lsid:ipni.org:names:60475908-2

Twining vine, vegetative growth annual, probably from a perennial tuber like the other members of the species complex but underground organs not seen. Indumentum absent. Stems left-twining, upper stem to $2 \mathrm{~mm}$ diam., shallowly longitudinally ridged, herbaceous, unarmed, dull purple in fresh material with paler to white ridges, mottled pale green to white between ridges, light brown when dry, stem base and cataphylls not seen. Leaves alternate, blade $1.2-6.5 \times$ $1.0-6.4 \mathrm{~cm}$, ovate to narrowly or broadly so in outline, 


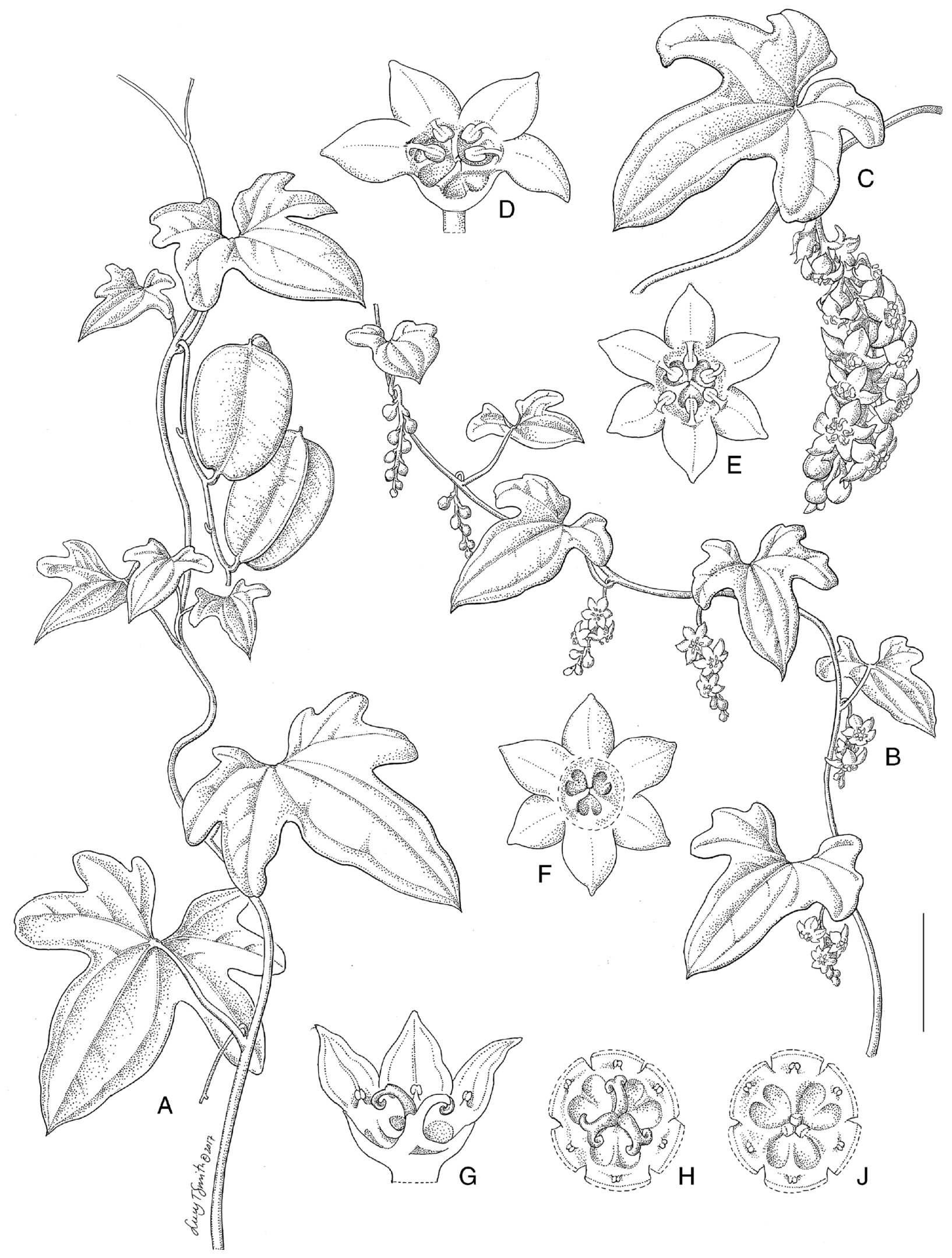




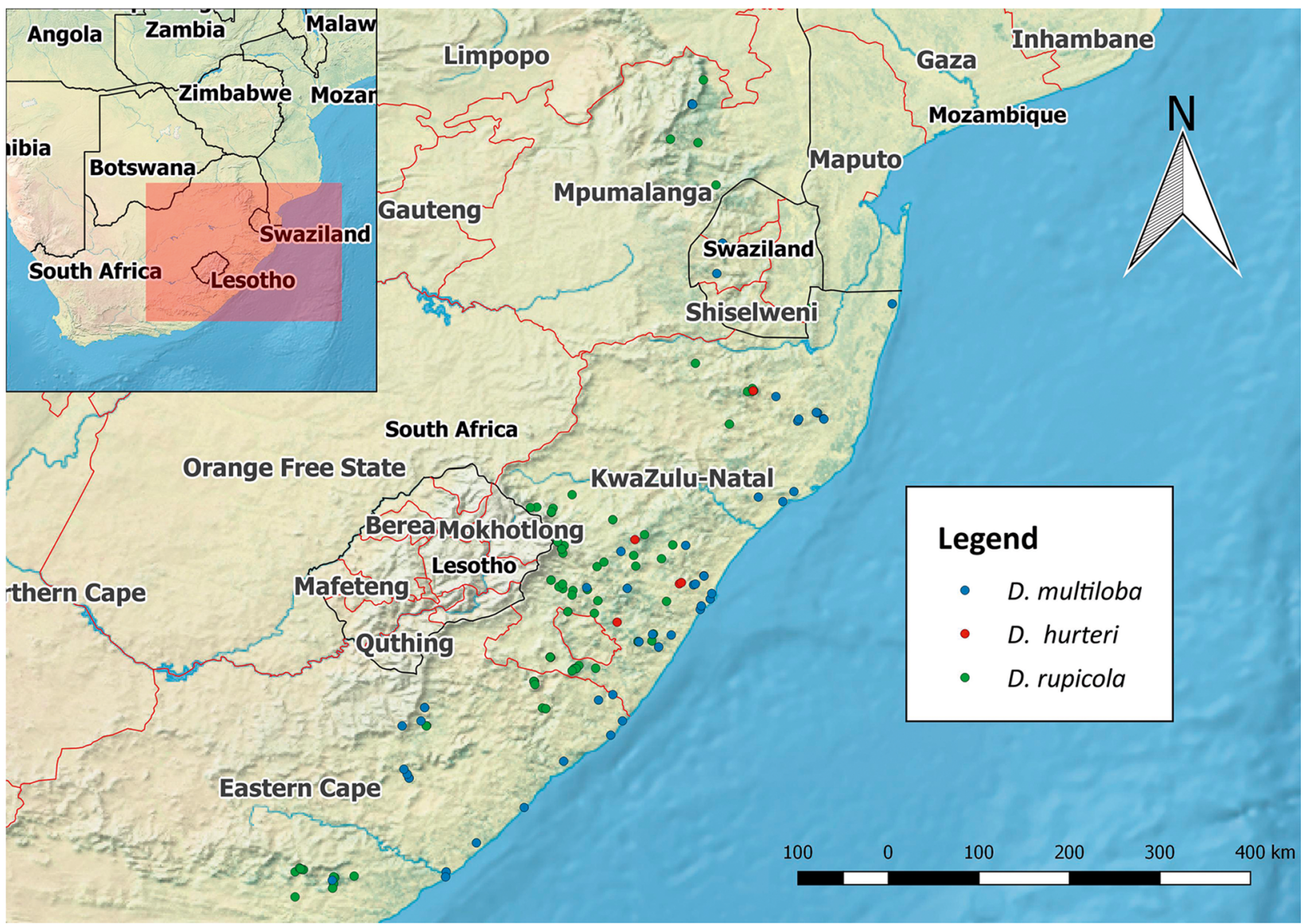

Map 1. A map of eastern South Africa showing the localities of Dioscorea hurteri (red circles), D. rupicola (green circles) and D. multiloba (blue circles). The red lines indicate provincial boundaries whilst the black lines are national boundaries.

margin with 3 or 5 shallow to deep lobes, lobing concentrated towards base close to point of petiole insertion, texture thinly chartaceous, base cordate, sinus $2-13 \mathrm{~mm}$ deep, lobes to $44 \mathrm{~mm}$ long, apically obtuse to rounded, apical lobe lanceolate, apex broadly acuminate, with a narrow, caudate forerunner tip to $5 \mathrm{~mm}$ long, derived from central 3 veins of blade, primary veins $5-7,3$ in apical lamina lobe, primary venation in shallow channels on upper surface in fresh material, lamina mid green above when fresh, paler below, maroon-purple pigmentation (concolorous with petiolar pulvinii) present around point of petiole insertion, at bases of primary veins and on forerunner tips, blades dark olive brown when dry; petiole $7-27 \times 0.3-0.7 \mathrm{~mm}$, longitudinally ridged with a narrow channel on upper surface, dull dark purple to pink or yellow green, with more strongly pigmented maroon-purple basal and apical pulvinii when fresh, petiole concolorous with stem when dry; lateral nodal organs absent but petiole base broader where inserted onto stem; axillary bubils absent. Male inflorescences simple, spicate, axis angular, 1 per axil, $6-34 \mathrm{~mm}$ long, colour as stem, peduncle 3-13 mm long, c. $1 \mathrm{~mm}$ in diameter at base, racemose, probably pendent, bearing flowers $0-3.0 \mathrm{~mm}$ apart, usually largely concealing inflorescence axis especially towards apex of inflorescence, on a $0.2-0.9 \mathrm{~mm}$ pedicel, buds patent to axis. Male flowers (sub)globose in bud, tepals 6 , inserted on a shallowly concave torus, spreading at anthesis, dark purple when fresh in bud, tepals maroon purple at anthesis but torus remaining darker, drying brown and translucent; floral bracts 1 per flower, $1.0-1.5 \times 0.3-0.7 \mathrm{~mm}$, ovate to lanceolate, longacuminate, paler brown than flower when dry; bracteole 1 per flower, similar, narrower and slightly shorter, offset from bract; tepal whorls weakly differentiated, inner slightly broader, outer tepals $1.9-2.7 \times 1.3-1.9(-2.3)$ $\mathrm{mm}$, inner $1.9-2.9 \times 1.6-2.5 \mathrm{~mm}$, both outer and inner ovate to narrowly so or deltate, apex acute to obtuse, slightly thickened and sometimes with upcurved margins but not cucullate, inserted on margin of $2.1-3.3 \mathrm{~mm}$ diameter fleshy torus, thicker than tepals and very dark purple when fresh, drying black; stamens 6 , inserted at torus/tepal boundary at tepal base midpoint, filaments $0.5-0.7 \mathrm{~mm}$ long, apically incurved, pale yellow; filament base vascular tissue ascending, appearing to curve upwards at the outer edge of the nectariferous depression (Fig. 1F) creating a sinus and the reniform to cordate shape; anthers $0.4-0.6 \times 0.25-0.4 \mathrm{~mm}$, oblong to oblong-elliptic in outline, basifixed, pale yellow with a 


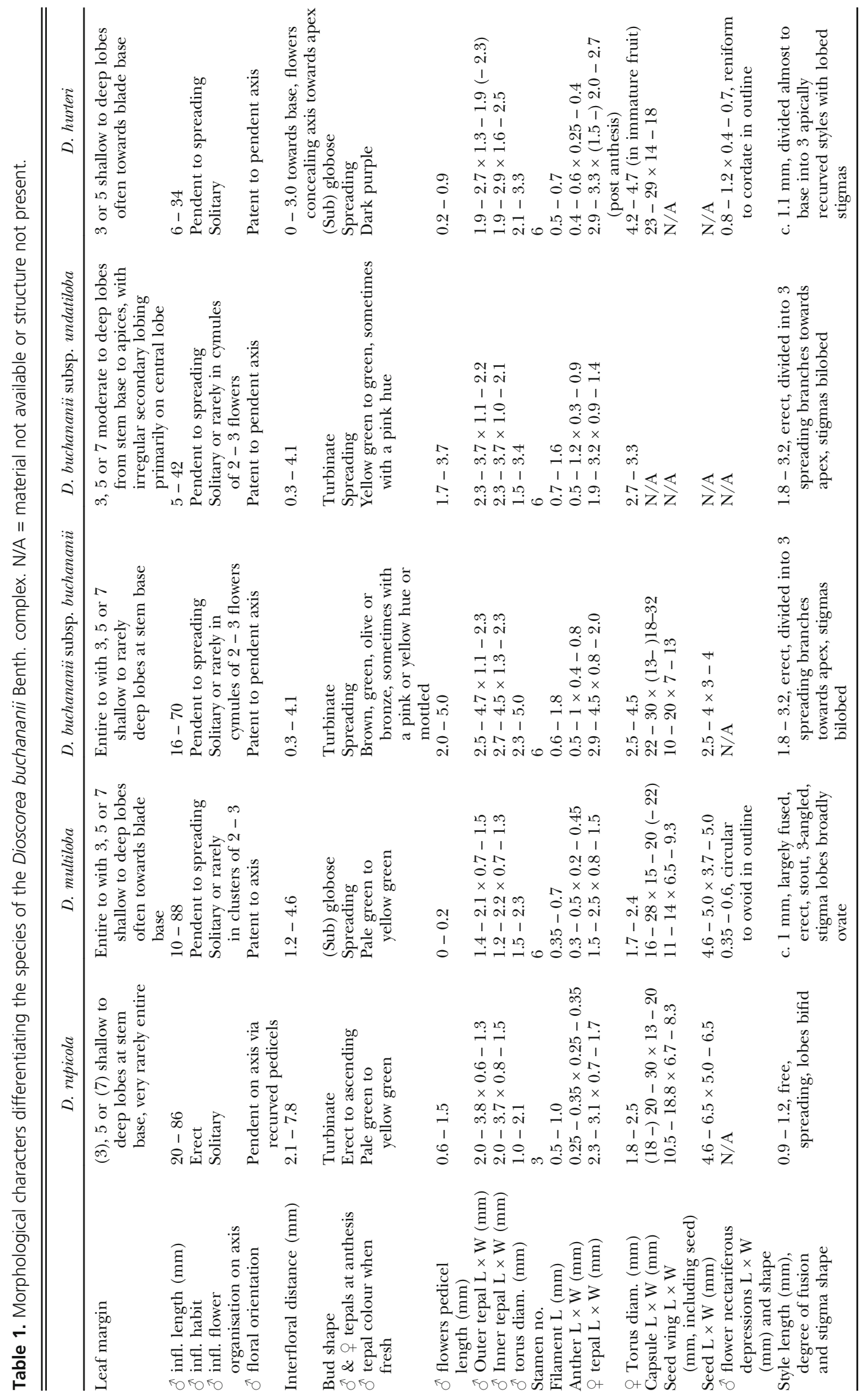


darker connective that is purple when fresh, held over nectariferous depressions in a circle; pistillode $0.3-0.7 \mathrm{~mm}$ long, variable in shape but formed by 3 centrally fused triangular ridges at $120^{\circ}$ to each other, raised on the lip of the torus with filaments inserted below, very dark purple, with a $0.8-1.2 \times 0.4-0.7 \mathrm{~mm}$ diameter, reniform to cordate, nectariferous depression between each lobe demarcated by a ridge on the inner side, with a denser texture than torus, white and contrasting with torus when fresh, drying pale brown. Female inflorescence pendent, length unknown, peduncle c. $15 \mathrm{~mm}$ long, interfloral distance c. $15 \mathrm{~mm}$ in immature fruit. Female flowers only seen in post anthesis state (ie immature fruit); tepals and torus apparently similar to male, former 2.9 - $3.3 \times(1.5-) 2.0-2.7 \mathrm{~mm}$, latter $4.2-4.7 \mathrm{~mm}$ diam. Styles free almost to base, 3, c. $1.1 \mathrm{~mm}$ high, apically recurved with lobed stigma, held between weakly reniform to cordate nectariferous depressions that are $0.8-1.2 \times 0.4-0.7 \mathrm{~mm}$ in diameter. Immature capsule 23 - $29 \times 14-18 \mathrm{~mm}$, oblong in outline, thick-chartaceous, base truncate, apex rounded, pale to dark brown. Seeds not seen at any stage of development. Figs 1, 2.

RECOGNITION. Dioscorea hurteri can be recognised through its dense, short, male inflorescences bearing dark purple flowers that are borne on $0.2-0.9 \mathrm{~mm}$ long pedicels, (sub)globose in bud and concealing the inflorescence axis towards its apex (see Figs 1, 2). Female plants have 3 subfree, apically recurved styles (Fig. 1G). Both male and female flowers possess nectariferous depressions in the torus that are unique in being $0.8-1.2 \times 0.4-0.7 \mathrm{~mm}$ and reniform to cordate in outline (Fig. 1D, F, H, J). They also appear to be white in fresh material in contrast to the very dark purple torus and pistillode.

DISTRIBUTION AND HABITAT. Endemic to South Africa in KwaZulu-Natal Province, herbrium specimens of Dioscorea hurteri have been collected in Karkloof, Drummond (near Camperdown) and Ixopo and photographed at Ngome (Fig. 2) at altitudes from 600 to $1200 \mathrm{~m}$. The sight records were obtained at sites immediately south of the Mzimkulu River in forest on a hillside called Nkoneni, which is $5 \mathrm{~km}$ ENE of Mtintanyoni in southern KwaZulu-Natal, near the Tugela at Kranskop and at Botha's Hill to the West of Durban (N. Crouch, pers. comm.). It can be seen in Map 1 that the distribution of $D$. hurteri is sympatric with D. rupicola and D. multiloba, and it appears to occur in areas where the two more widespread species meet; they have largely distinct ecologies and altitudinal ranges as described in Wilkin \& Muasya (2015). The Moore s.n. specimen from Drummond was collected from kloof forest.
Fig. 2. The male plant of Dioscorea hurteri. A leaf form and a pendent inflorescence, at Ngome c. 2002. B stem pigmentation, short, dense inflorescences and more or less globose buds and flowers at anthesis showing purple tepals and a darker torus and pistillode, the former with three white nectariferous depressions per flower. $\mathrm{C}$ habit and inflorescences; the thicker leaf in the centre of the image is Dioscorea cotinifolia Kunth, upon which $D$. hurteri was climbing (B \& C 9 Dec. 2017 at Botha's Hill West of Durban). PHOTOS: A GARETH CHITTENDEN; B \& C NEIL CROUCH.

Other associated vegetation, geology and soils are not recorded in any of the remaining specimens. The sight records were from mesic to dry forests growing in shade, often in thin humus-rich soils overlying sheetrock (N. Crouch, pers. comm.).

SPECIMENS EXAMINED. SOUTH AFRICA. KwaZulu-Natal: Camperdown, Drummond $\widehat{\jmath}$ fl. Oct. 1964, Moore s.n. (NH!, holotype); Collected at Ixopo and cultivated at Irene $\delta$ fl. 20 Dec. 1954, Pole-Evans 4854 (K!, NH, PRE); Camperdown, Drummond ô fl. 15 Jan. 1967, Strey 7308 (NH digital image!); Collected at Lions R., Karkloof and cultivated at Irene $q$ fl. 20 Dec. 1954, Pole-Evans 4862 (K!, PRE).

VERNACULAR NAME. Not known.

CONSERVATION STATUS. Dioscorea hurteri is endemic to KwaZulu-Natal, where there has been extensive development for agriculture and human settlement; this threat is ongoing. This species has an EOO $(9,872$ $\mathrm{km}^{2}$ ) within the Vulnerable threshold of the IUCN Red List and is known from only six locations with habitat loss from development being the single most plausible threat to each location. Two of the locations potentially occur within protected areas; the Karkloof Nature Reserve and Ngome forest that forms part of the Ntendeka Wilderness Area. It is reported to be abundant where it occurs (N. Crouch, pers. comm.), although he only found male plants at the three sites listed above. AOO was not used in the provisional assessment because it represents the minimum AOO based on georeferenced point data and is not supported by recent field surveys This indicates that $D$. hurteri should provisionally be viewed as Vulnerable Blab(iii) using the IUCN Red List criteria (IUCN 2001).

USES. None known.

ETYMOLOGY. Named for Johan Hurter, who inspired many people to study South African Dioscorea, including the last author.

NOTES. The specimen Moore s.n. was selected as the type because Pole-Evans 4854 and 4862 were cultivated. This may have had an effect on the vegetative morphology of the plant. The specimen is more representative than Strey 7308, which appears to have many flowers that are post-anthesis, having been collected in January as opposed to October in the type collection. 

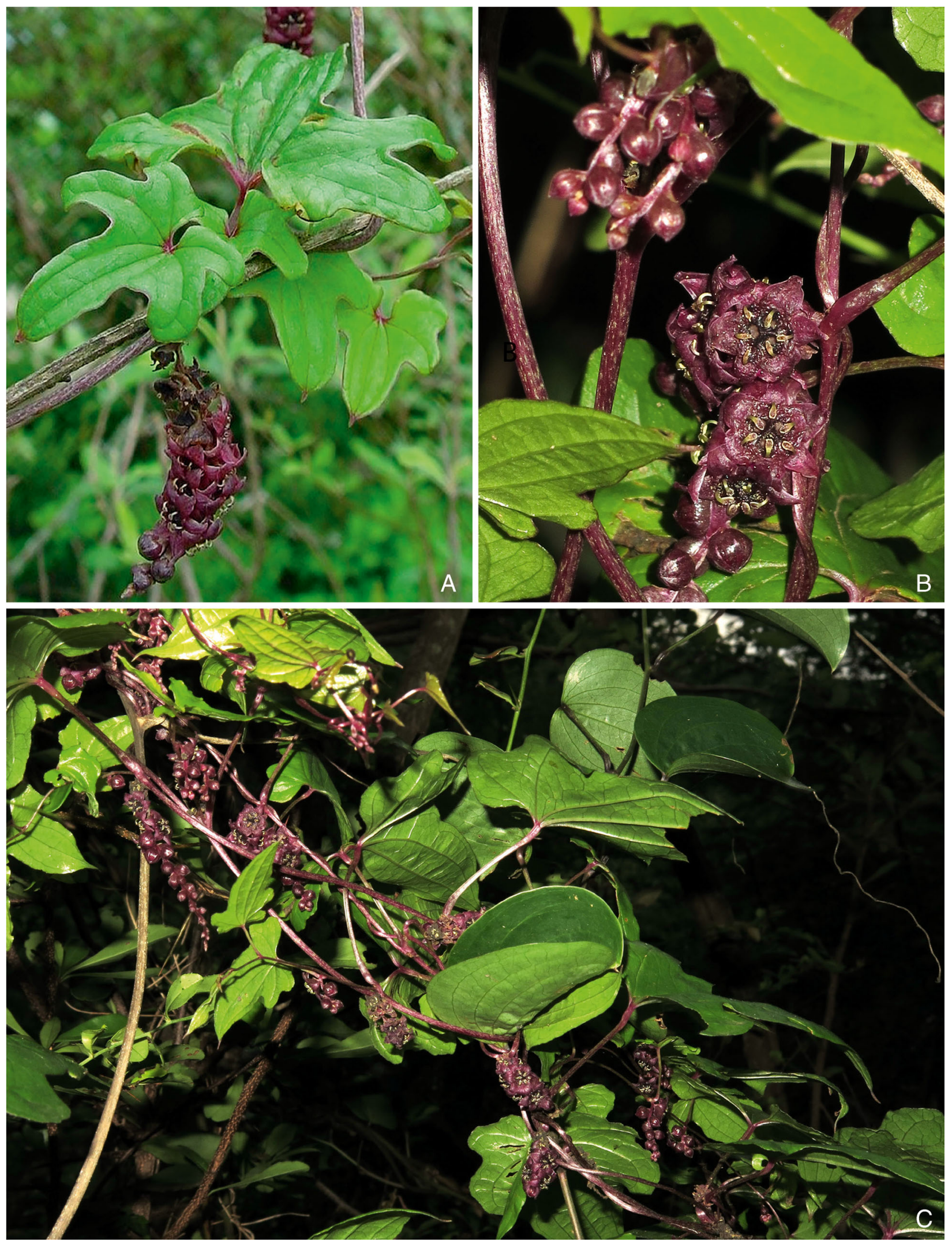


\section{Keys to Dioscorea species in KwaZulu Natal}

\section{Key to male plants}

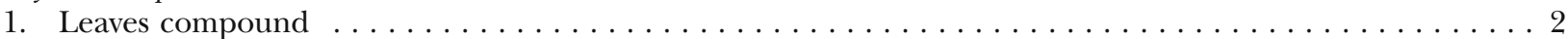
Leaves entire to deeply lobed but not divided into separate leaflets $\ldots \ldots \ldots \ldots$

2. Leaflets 3 , with at least 3 veins per leaflet reaching apex $\ldots \ldots \ldots \ldots \ldots$. . . . . . . . D. dregeana

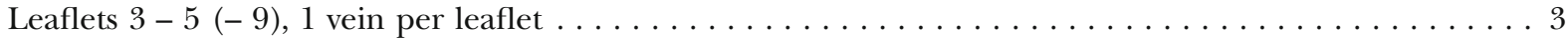

3. Floral bracts $2.3-6.7(-8.5) \mathrm{mm}$ long, obscuring inflorescence rachis, leaf margins flat . . . D. quartiniana Floral bracts $1.5-2.7 \mathrm{~mm}$ long, inflorescence rachis visible, often has undulate leaf margins . . . D. retusa

4. Stems twining to the right, leaves entire, usually opposite, tepals erect and overlapping at anthesis making flowers urn-shaped, outer tepals ovate or elliptic $\ldots \ldots \ldots \ldots \ldots \ldots \ldots \ldots \ldots$. . . . . . . . . . . . . . . . . Stems twining to the left or non-twining, leaves alternate, flowers not as above $\ldots \ldots \ldots$

5. Non-twining, erect stems to c. $1 \mathrm{~m}$, usually with short internodes and more or less lanceolate leaves, in tall mistbelt and montane grassland on forest margins $\ldots \ldots \ldots \ldots \ldots \ldots \ldots \ldots \ldots$ brownii Stems twining and leaves not as above, always associated with and climbing on woody vegetation . . . . .6

6. Leaves entire to with 2 rounded basal lobes. Floral torus c. $1 \mathrm{~mm}$ in diam., stamens 6 ; tepals narrowly oblong to

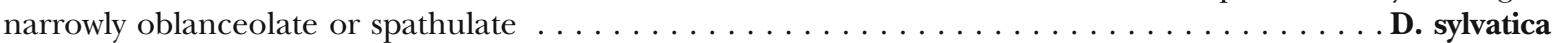

Leaves rarely entire, usually with 2, 4 or 6 more or less oblong basal lobes. Floral torus at least $1.5 \mathrm{~mm}$ in diam. or if not stamens 3 ; tepals narrowly ovate to lanceolate or deltate $\ldots \ldots \ldots \ldots \ldots$

7. Stamens 6 , inflorescences spreading to pendent, tepals spreading, apices flat . . . . . . . . . . . Stamens 3, inflorescences erect, and bearing flowers patent to axis to recurved towards its base, tepals erect to

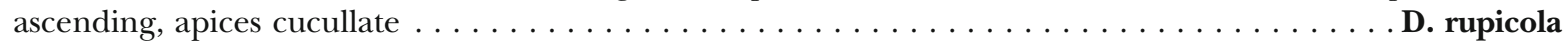

8. Leaves consistently moderately to deeply 3, 5 or 7-lobed from stem bases to apices, with irregular, pinnate secondary lobing present on central lobe at least, nectariferous depressions on torus absent, floral buds

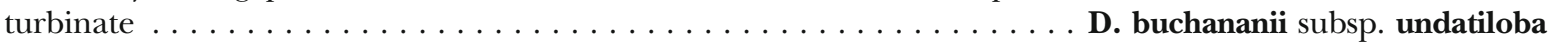
Leaves shallowly to moderately 3,5 or 7-lobed or rarely entire, lacking any pinnate secondary lobing. Nectariferous depressions on torus present, floral buds $($ sub)globose $\ldots \ldots \ldots \ldots$

9. Flowers on $0.2-0.9 \mathrm{~mm}$ long pedicels, purple, torus diam. $2.1-3.3 \mathrm{~mm}$, nectariferous depressions $0.8-1.2 \times$ $0.4-0.7 \mathrm{~mm}$, reniform to cordate in outline $\ldots \ldots \ldots \ldots \ldots \ldots \ldots \ldots$ hurteri Flowers sessile to $0.2 \mathrm{~mm}$ long, yellow-green to pale green, torus diam. $1.5-2.3 \mathrm{~mm}$, nectariferous depressions $0.35-0.6 \mathrm{~mm}$ in diam. and circular to ovoid in outline

D. multiloba

Key to female plants

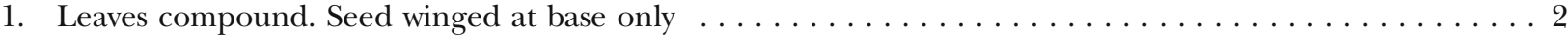
Leaves entire to deeply lobed but not divided into separate leaflets, seeds apically winged or winged all

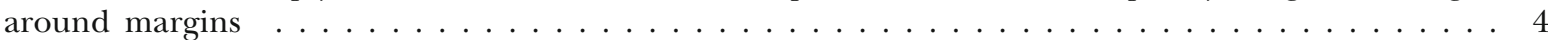

2. Leaflets 3, with at least 3 veins per leaflet reaching apex. Capsule $3.8-5 \mathrm{~mm}$ long . . . . . D. dregeana Leaflets $3-5(-9), 1$ vein per leaflet. Capsule $1.5-3.4 \mathrm{~mm}$ long $\ldots \ldots \ldots$

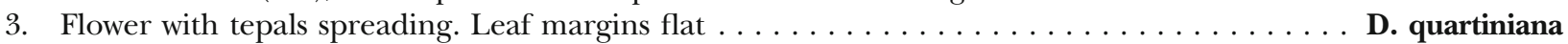
Flower with tepals erect. Leaf margins often undulate $\ldots \ldots \ldots \ldots \ldots \ldots \ldots \ldots \ldots$

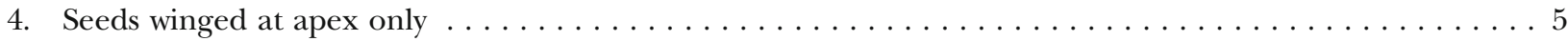
Seeds winged all around the margin with a wing that is longer than wide (often oblong-elliptic $\ldots \ldots \ldots 7$

5. Stems non-twining, erect, to c. $1 \mathrm{~m}$, usually with short internodes and more or less lanceolate leaves, in tall

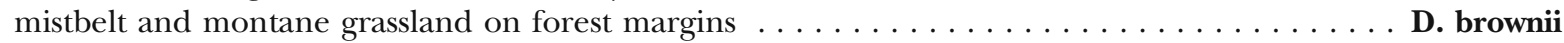
Stems twining and leaves not as above, always associated with and climbing on woody vegetation $\ldots \ldots .6$

6. Stems twining to the right, leaves entire, usually opposite, outer tepals $1.2-1.6 \mathrm{~mm}$ long . . . D. cotinifolia Stems twining to the left, leaves alternate, entire to with 2 rounded basal lobes, outer tepals 1.6 -

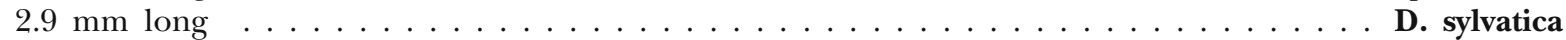

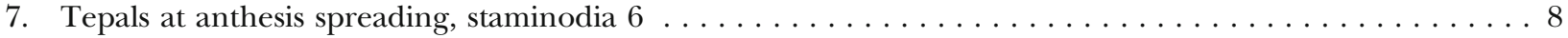
Tepals at anthesis erect, staminodia $3 \ldots \ldots \ldots \ldots \ldots \ldots \ldots \ldots \ldots$. . . . . . . . . . . . . . .

8. Leaves consistently moderately to deeply 3, 5 or 7-lobed, with irregular, pinnate secondary lobing present on central lobe at least. Nectariferous depressions on torus absent . . . . . . D. buchananii subsp. undatiloba Leaves shallowly to moderately 3, 5 or 7-lobed or rarely entire, lacking any pinnate secondary lobing.

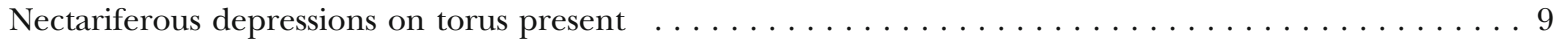


9. Torus diam. $4.2-4.7 \mathrm{~mm}$ (in immature fruit), nectariferous depressions reniform to cordate in outline, styles

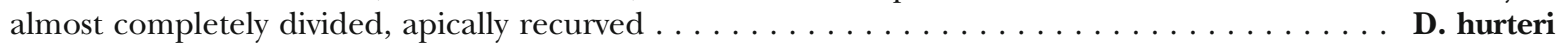
Torus diam. $1.7-2.4 \mathrm{~mm}$, nectariferous depressions circular to ovoid in outline, styles fused, erect, stout and 3-angled with only the three stigmatic surfaces free and spreading . . . . . . . D. multiloba

\section{Acknowledgements}

We must thank the curators of the herbaria listed above for access to specimens, and especially Yashica Singh for organising the loan of the holotype specimen. Thanks are due to Steve Bachman, Lize von Staden and Felix Forest for their assistance in the MSc thesis that instigated the production of this MS. Thanks are also due to the two anonymous reviewers for their constructive comments and for enhancing the clarity of the text. Finally, major thanks are due to Neil Crouch and Gareth Chittenden for allowing the use of their photographs in Fig. 2 and the former also for sight locality and field data. Both greatly improved this paper.

Open Access This article is distributed under the terms of the Creative Commons Attribution 4.0 International License (http://creativecommons.org/ licenses/by/4.0/), which permits unrestricted use, distribution, and reproduction in any medium, provided you give appropriate credit to the original author(s) and the source, provide a link to the Creative Commons license, and indicate if changes were made.

\section{References}

Bachman, S., Moat, J., Hill, A. W., de la Torre, J. \& Scott, B. (2011). Supporting Red List threat assessments with GeoCAT: geospatial conservation assessment tool. In: V. Smith \& L. Penev (eds), eInfrastructures for data publishing in biodiversity science. Zookeys 150: 117 - 126 (Version BETA).
Hills, R. (2016). How does evolutionary history affect conservation assessments of South African Dioscorea (Dioscoreaceae)? Unpubl. MSc. Thesis.

et al. Incorporating evolutionary history into conservation assessments of a highly threatened group of species, South African Dioscorea (Dioscoreaceae). MS in prep.

IUCN (2001). IUCN Red List Categories and Criteria: Version 3.1. IUCN Species Survival Commission. IUCN, Gland and Cambridge.

IUCN Standards and Petitions Subcommittee (2014). Guidelines for using the IUCN Red List Categories and Criteria. Version 11. Prepared by the Standards and Petitions Subcommittee. Downloadable from http:/ / www.iucnredlist.org/documents / RedListGuidelines.pdf [accessed 2016-04-07].

Maurin, O., Muasya, A. M., Catalan, P., Shongwe, E. Z., Viruel, Wilkin, P. \& van der Bank, M. (2016). Diversification into novel habitats in the Africa clade of Dioscorea (Dioscoreaceae): erect habit and elephant's foot tubers. Bio Med Centr. Evol. Biol. 16: 238.

Quantum GIS Development Team (2017). Quantum GIS Geographic Information System. Open Source Geospatial Foundation Project. Downloadable from http:/ / qgis.osgeo.org [accessed 2017-03-03].

Wilkin, P. (2001). Yams of South-Central Africa. Kew Bull. 56: 361 - 404.

(2009). Dioscoreaceae. In J. Timberlake (ed.), Flora Zambesiaca 12 (2): 109 - 140. Royal Botanic Gardens, Kew.

\& Muasya, A. M. (2015). Clarifying the Dioscorea buchananii Benth. species complex: a new subspecies for South Africa that may already be extinct. Phytokeys 48: 51 - 72. 